\title{
Quaternary Sea Levels of the unes: Brazilian Coast: Recent Progress
}

\author{
by Kenitiro Suguio, Louis Martin and Jean-Marie Flexor
}

Major contributions to the study of variations in sea level have come from recent work along the coast of Brazil, and Brazilian data were an important contribution to the recent IGCP sea-level projects described in the last issue of

Episodes by P.A. Pirazzoli. Several raised marine levels have been recognized older than 123,000 yB P and associated with older interglacials, but the most detailed chronology concerns a series of raised shoreline features formed during the past 7,000 years. Certain differences from one coastal sector to another are attributed to variations of the geoid surface, or to local tectonics, and a detailed model for the Holocene evolution of the central and southern Brazilian coast is presented. (Ed.)

\section{Introduction}

Until recent years, the ancient shorelines of regions such as Brazil, then regarded as stable, were considered to be records of past global ocean levels. One of the goals of the two IGCP projects (61 and 200) on sea levels was to determine a worldwide eustatic curve for the Holocene (see Pirazzoli, 1988). However, field observations conducted in many countries very quickly showed that this was not a realistic undertaking, and all specialists now accept that it is possible only to define local or regional, not global, curves. It is evident that coastal zones in different areas can be at the same time stable, submerged, or emerged and, consequently, there can be no general model of coastal evolution. Thus, so-called eustatic curves, such as that of Fairbridge (1961), cannot be used as models of relative sea-level variations over recent millennia.

The important role played by sea-level variations in the evolution of the Brazilian coast line was observed very early, and many authors have described the record of these oscillations. Early workers interpreted the evidence, mostly morphological in nature, as indicating a Tertiary age, but later studies have emphasized Quaternary events. However, prior to the 1970 s systematic studies of relative sea-level changes along the Brazilian coast were fairly rare.

Fluctuations in sea levels over the past 7,000 years have been systematically studied since 1974 by scientists from the University of São Paulo, the Federal University of Bahia, and the National Observatory $(\mathrm{CNPq})$ through a joint project with the Institute of Scientific Research for the Development in Cooperation (ORSTOM) in France. Studies have been completed on the Quaternary coastal formations of the states of São Paulo, Rio de Janeiro, Bahia, Sergipe, Alagoas, northern Espírito Santo, Paraná, and Santa Catarina. The same team has made systematic surveys of sedimentary deposits at the mouths of the Paraiba do Sul, Doce, Jequitinhonha and São Francisco rivers, in order to determine the role played by sea-level variations and by littoral drift in the construction of these coastal plains. The Quaternary coastal marine deposits of Rio Grande do Sul have been investigated by a team from the Federal University of that state (Villwock et al., 1986). The most important conclusions from these studies have been reviewed by Suguio and others (1985) and Martin and others (1987).

\section{Factors Governing Changes in Sea Levels}

Reconstructions of ancient sea levels represent relative and not absolute positions, because relative sea-level changes (Fig. 1) are the result of widespread variation of sea level (eustasy), and of variations in the elevation of continents. The latter are mainly controlled by horizontal or vertical tectonic movements over time scales ranging from longterm to instantaneous (seismic), or by isostatic movements related to variations in the loading of land surfaces due to the formation and disappearance of ice caps, the erosion of continents and accumulation of sediments in sedimentary basins, and transgressions and regressions on continental shelves (hydro-isostasy).

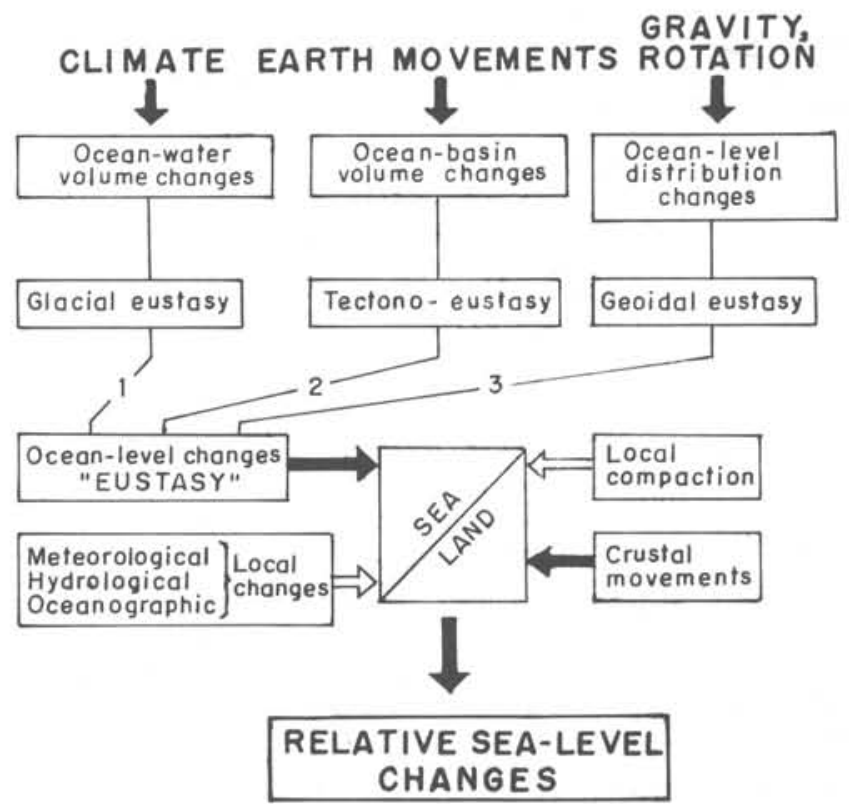

Figure 1: Mechanisms governing changes in sea level. After Mörner (1980).

Changes in the level of the ocean surface are also controlled by variations in the volume of oceanic basins as a consequence of plate tectonics (tectono-eustasy), and in the volume of water in oceans connected with glaciation and deglaciation (glacial-eustasy). Deformation of the continental geoid (the current reference surface) or of the ocean surface (geoidal-eustasy) also induce sea-level variations.

The height of the marine surface has oceanic and geophysical components. The former include tides, major currents and associated whirlpools, and slope variations due to wind pressure, water temperature and salinity. The total effect of these does not exceed 1 to $2 \mathrm{~m}$, and thus is quite small compared to the enormous marine surface hollows and 
bumps caused by density heterogeneities within the Earth's interior. This geophysical component corresponds to the geoid, which is essentially the average sea level.

Starting in 1975, altimeters on the GEOS 3 and SEASAT satellites made it possible to measure the position of the sea surface with extreme precision and thus to demonstrate the existence of undulations with very long wavelengths and with amplitudes of several dozen metres (up to $100 \mathrm{~m}$ to the south of India). The absence of correlation between these undulations and the surface on the one hand, and their amplitudes and wavelengths on the other, indicates that they may be attributed to density differences in the lower mantle, or even at the core-mantle interface. At shorter wavelengths, the marine geoid exhibits a highly varied spectrum of anomalies in elevation.

The geoid is an equipotential surface of the gravity field, determined by the forces of rutation and gravity that affect the planet Earth. These forces, and hence the geoid shape, vary as a function of core and mantle compositions, and of the relationship between asthenosphere and lithosphere. Several orbital phenomena and their interactions may also affect the geoid. According to Mörner (1984) geoid surface modifications can occur rapidly (up to $10 \mathrm{~mm} / \mathrm{year}$ ), with gradients of several metres per kilometre. One milligal change in the force of gravity can deform the ocean surface by $3.3 \mathrm{~m}$, and the surface of the Earth's crust by $1.7 \mathrm{~m}$.

The ocean level at any given point on the crust is, thus, the instantaneous product of complex interactions between the surfaces of the ocean and the continent. Changes in the volume of oceans exert their effects on a global scale. Variations in the geoid surface and in continental levels also exert an influence on local and regional scales. It is not, therefore, surprising that inconsistencies exist among sealevel reconstructions for the same time period but at different points of the globe. This is particularly so for the past 7,000 years, prior to which the rate of glacio-eustatic rise was fast enough to mask effects due to local or regional factors.

\section{Reconstructing Ancient Sea-level Positions}

To reconstruct a past relative sea-level position, it is necessary to define a marker for it in time and space. The latter can be established by determining its present elevation with respect to its original one, that is, its position with respect to sea level at the time of its formation (Van de Plassche, 1986). The age of formation or deposition of the marker must also be determined, using archeological or other dating methods. A marker thus defined gives a position of an ancient sea level at a certain time relative to the present sea level. If sufficiently numerous data can be collected covering a certain period of time, a variation curve for this period can then be plotted.

Evidence for Quaternary marine levels comes from several sources. Sandy littoral deposits whose tops are very much above present equivalent deposition zones provide indisputable evidence for former raised marine levels. Detailed mapping together with absolute age determinations have led to the distinction between two principal generations of sandy terraces, recording two periods of high Quaternary marine stands.

Along almost all the rocky portion of the Brazilian coast, there is also biological evidence for old marine levels higher than at present. This generally consists of oyster and limpet (gastropod) deposits and of sea-urchin holes situated above the present living zone of these organisms. Since the distribution zone of limpets is very narrow $(0.5 \mathrm{~m})$, the presence of a fossil deposit of these organisms makes it possible to reconstruct an old sea level with precision. All along the nort heastern part of the Brazilian coast, there are also numerous dead reefs made up of calcareous algae and coral. The position and morphology of peaks of these reefs provide evidence for former raised sea levels. In sandy terranes one can also find fossilized burrows of Callichirus major (a marine arthropod) above their present living zone.

Numerous "sambaquis" (anthropogenic accumulations of shells) built by ancient inhabitants of the coastal zones can be found along various parts of the Brazilian shoreline. The position of some of these sambaquis can be explained only by a lagoon extension significantly greater, and hence higher, than at present. Moreover, sambaquis whose bases are below the present high-tide could have been built only at a time when sea level was lower than at present.

\section{High Marine Levels During the Quaternary in Brazil}

The oldest high sea level ( $>123,000 \mathrm{yBP}$ ) has been recognized in the southern State of Rio Grande do Sul (Fig. 2), where it is represented by marine terraces about 20-25 m high, superficially reworked by eolian processes (Villwock et al., 1986) and known as Barrier I (Fig. 3). Its absolute age is uncertain, but it is probably related to older interglacial stades.

Another event older than $123,000 \mathrm{yBP}$ is the "Old Transgression" recognized along the coast of the states of Bahia, Sergipe and Alagoas. This event is not, however, well defined, because no deposits outcrop along the cliffs cut through continental Pliocene sediments of the Barreiras Formation. Recently, Martin and others (in press) have regarded marine terraces at least $13 \mathrm{~m}$ above present MSL (mean sea level) along the coastal plains of the states of São Paulo, Paraná and Santa Catarina, as older than the Barrier III of Rio Grande do Sul (Fig. 3), and probably older than 123,000 yBP - tentatively middle Pleistocene.

A high marine level corresponding to the last Pleistocene interglacial stade (Barrier III in Fig. 3) left the most important records represented by extensive beach ridge

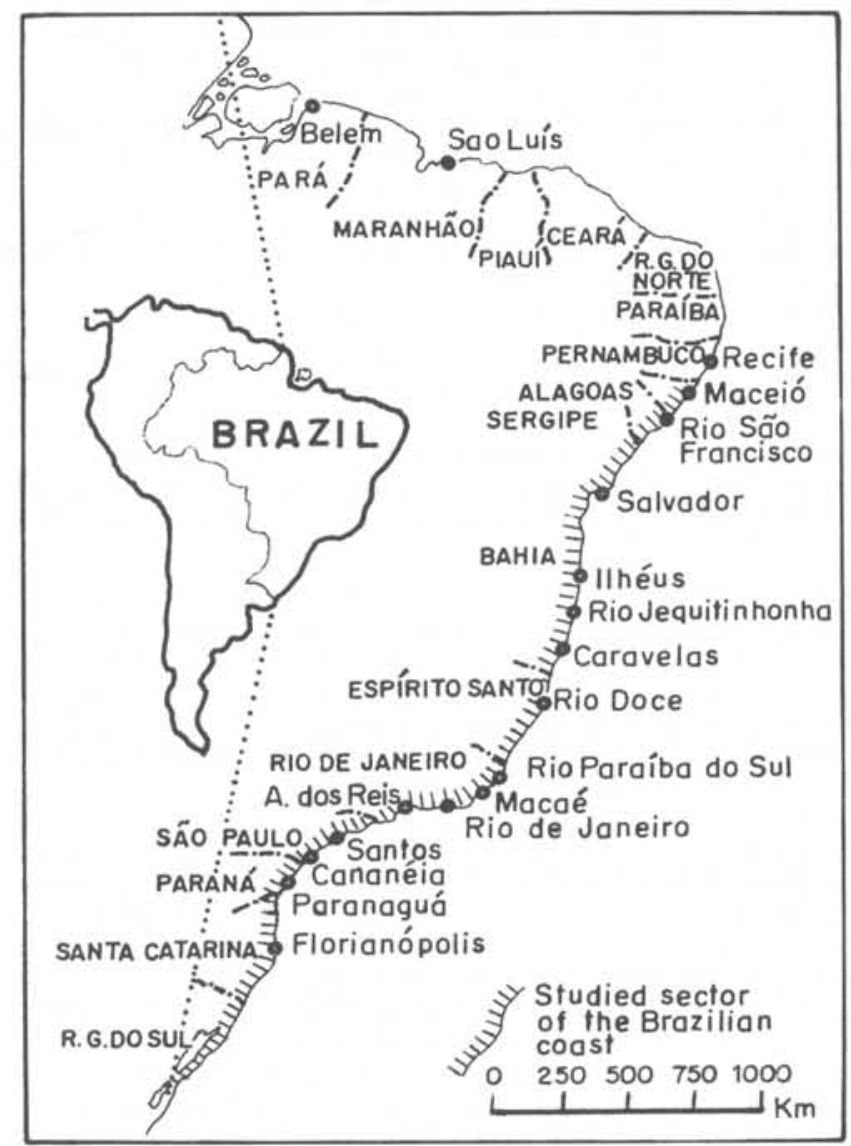

Figure 2: The sectors studied along the Brazilian coast. After Martin and others (1987). 
plains along the central and southern coast of Brazil. This phase is known as the Cananéia Transgression along the São Paulo coastline, and as the Penultimate Transgression in Bahia, Sergipe and Alagoas. During its maximum level, which has been dated at $123,000 \pm 5700 \mathrm{yBP}$ by coral samples, the relative sea level was situated $8 \pm 2 \mathrm{~m}$ above present MSL.
For the $60 \mathrm{~km}$ Santos sector about 30 reconstructions, resulting in a fairly complete curve, are available (Fig. 4E). It is interesting to note that the present zero was exceeded for the first time around 6,800 years ago, appreciably later than in the Salvador sector. However the same maxima can be observed at 5,100 and $3,600 \mathrm{yBP}$, positioned $4.5 \pm 0.5 \mathrm{~m}$ above present MSL.

\section{Holocene Levels: The Variation Curves}

The last transgressive-regressive phase, known as the Santos Transgression in São Paulo, is represented in Rio Grande do Sul by Barrier IV deposits about 3 to $4 \mathrm{~m}$ high (Fig. 3). The last 7,000 years of this transgression are very well known, due to numerous sedimentary, biological and prehistorical data gathered along the Brazilian coast (Suguio et al., 1985) and fixed by more than 700 radiocarbon determinations. The position of a number of sambaquis, together with dating of the shells they contain and with the $813 C_{\text {PDB }}$ values of earbonate of these same shells, have yielded interesting information about relative sea-level oscillations over the last 5,500 years. On the basis of all these data, it has been possible to plot relative sea-level variation curves for several coastal sectors of limited extent and uniform geological characteristics (Fig. 4).

In the Salvador sector, some $50 \mathrm{~km}$ in length, about 60 determinations of old relative sea-level positions have been made. As can be seen in Figure $4 \mathrm{~A}$, the present zero (mean level) was exceeded for the first time in the Holocene around $7,000 \mathrm{yBP}$. About 5,100 years ago the relative sea level went through a first maximum of $4.8 \pm 0.5 \mathrm{~m}$ above present MSL, after which there was a rapid regression until $4,900 \mathrm{yBP}$, slowing down until 4,200 yBP, and speeding up again until 3,900 yBP. At about this time the marine level passed through a minimum, probably below present sea level.

Between 3,900 and $3,600 \mathrm{yBP}$, a rapid transgression occurred, and about 3,600 years ago, the relative sea level passed through a second maximum of $3.5 \pm 0.5 \mathrm{~m}$ above MSL. Relative sea level then rose very rapidly between 2,700 and $2,500 \mathrm{yBP}$, passing through a third maximum of $2.5 \pm 0.5 \mathrm{~m}$ above the present level about 2,500 years ago. Since then the relative sea level has fallen steadily to its present position. This very well-defined curve can be used as a reference for other coastal sectors where the number of reconstructions is insufficient to allow a complete curve to be plotted.

In the $60 \mathrm{~km}$-long Ilheus sector, the number of reconstructions is insufficient for a complete curve to be drawn, but the available determinations exhibit no shift with respect to the Salvador curve (Fig. 4B). It has been possible to demonstrate the presence of three sandy terranes, witnessing the existence of three high-level positions, situated between 5 and 4,4 and 3 , and 3 and $2 \mathrm{~m}$ above the present MSL. It is logical to conclude that these terraces correspond to the maxima determined in the Salvador curve.

For the $30 \mathrm{~km}$ Caravelas sector only 11 reconstructions are available, seven of which fit into the range between 7,000 and 5,700 yBP (Fig. $4 \mathrm{C}$ ). All the available data are again in accordance with the Salvador curve.

At Angra dos Reis (Fig. 4D) only 17 old relative sea-level positions could be reconstructed over a $60 \mathrm{~km}$ coastal sector. However, the segment of the curve running back to 2,500 years ago is fairly well defined. Two maxima have been observed, one slightly above $3 \mathrm{~m}$ between 3,650 and $3,450 \mathrm{yBP}$ and the other approximately $4.8 \mathrm{~m}$ at about 5,200 years ago.

Figure 3: Four periods of high Quaternary marine levels (Barriers I to IV), along the coast of Rio Grande do Sul. Modified from Villwock and others (1986).

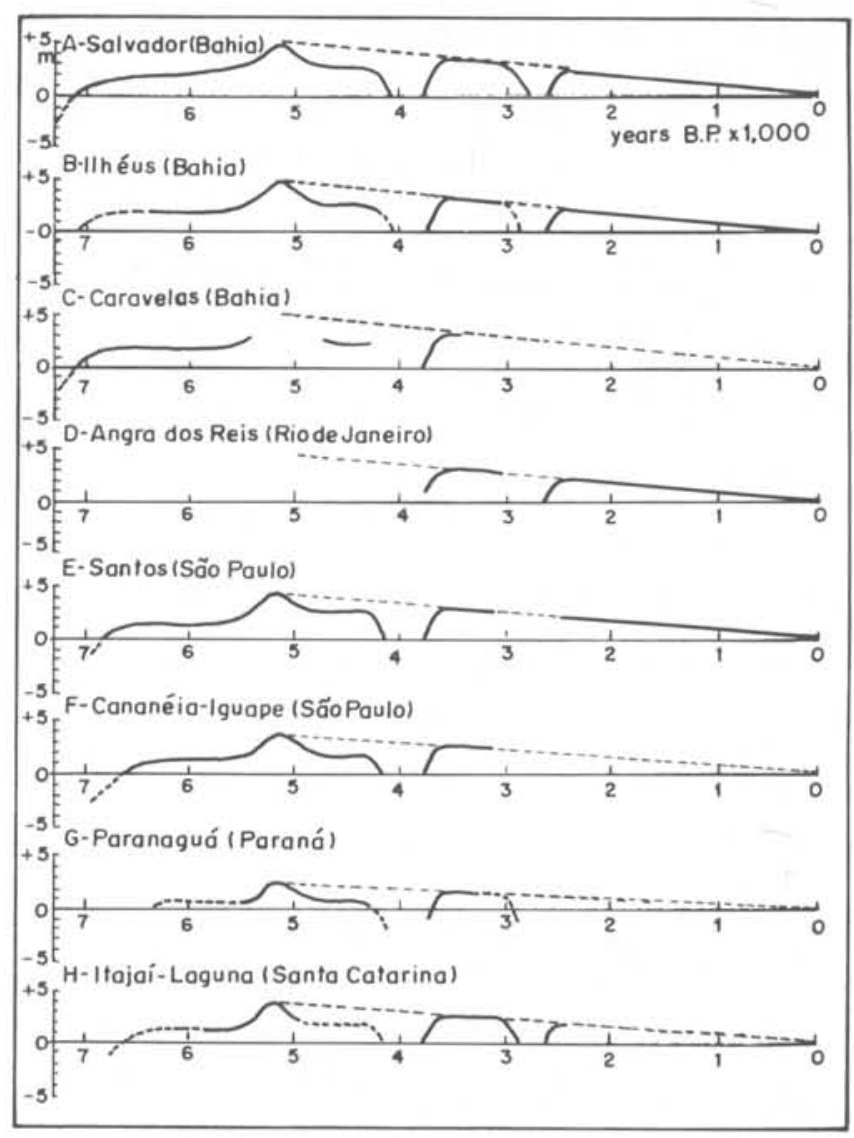

Figure 4: Relative sea-level variation curves for the last 7,000 years for different sectors of the Brazilian coast. Vertical scale: metres above or below present mean sea-level. After Suguio and others (1985). 
Only ten old relative positions could be reconstructed along the Cananéia sector, approximately $100 \mathrm{~km}$ long (Fig. 4F). However, as seven of them fell into the range between 6,650 and $5,300 \mathrm{yBP}$, that part of the curve was drawn up satisfactorily. Moreover, sambaquis datings associated with ${ }^{813} \mathrm{C}$ determinations provide additional information for this region. It seems that the present zero was exceeded for the first time about 6,600 years ago and the maximum at 5,150 yBP (whose age was established with great precision by means of the ${ }^{813} \mathrm{C}$ variation curve) was no higher than $4 \mathrm{~m}$ above the present zero.

Few good data are available from the $50 \mathrm{~km}$-long Paranaguá sector (Fig. 4G). Nevertheless, a few bits of precise information bring to light major trends. For instance, in Paranaguá Bay the peak of the outer part of Pleistocene marine terrace is about $2.5 \mathrm{~m}$ above present high tide. Given that on the surface of this terrace there are traces of old Pleistocene littoral belts, it is clear that the terrace was not submerged during the Holocene, and consequently that, at time of the 5,150 yBP maximum, relative sea level could not have been more than $2.5 \mathrm{~m}$ above present MSL. The Paranaguá curve is comparable in shape to that of Salvador, but shifted downwards by a sub-stantial amount.

Information available on the Quaternary of the coast of Santa Catarina State provides an understanding of the major sea-level variation trends over the last 7,000 years (Fig. 4H). The resulting curve for Itajai-Laguna, close to

\section{E-W section through Recôncavo Basin (Bahia)}
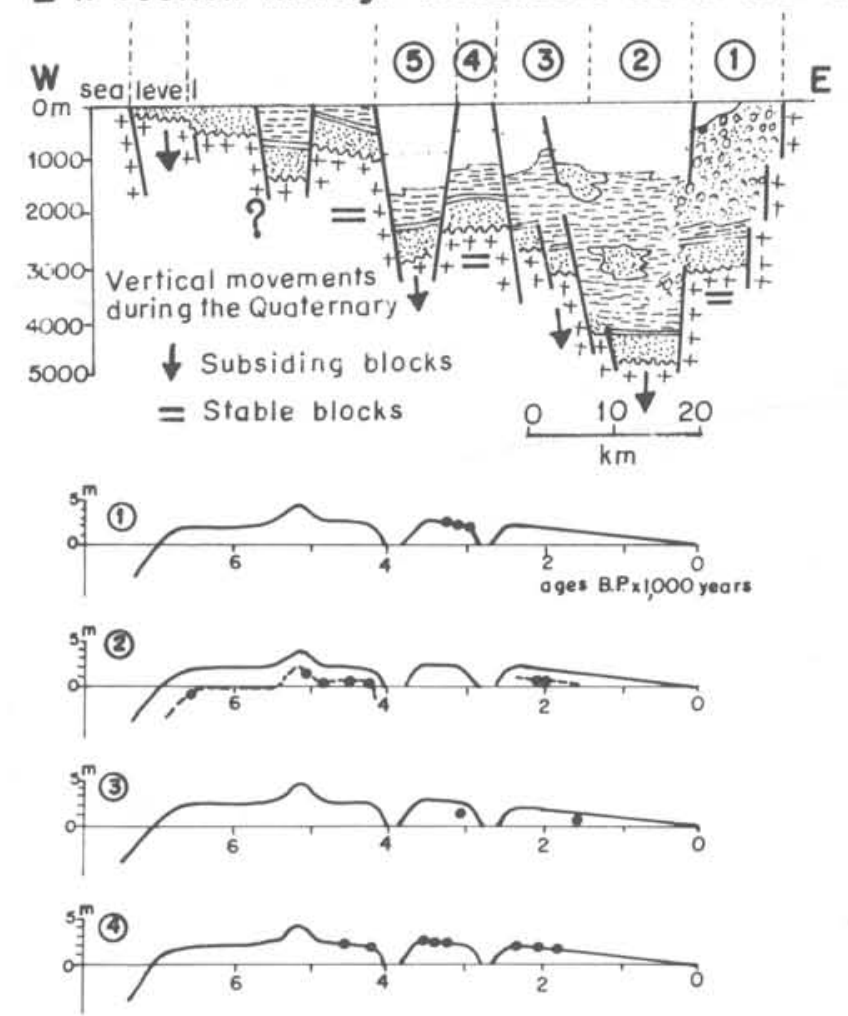

Figure 5: Profile across the faulted blocks of the Reconcavo Basin, State of São Paulo. Dashes: clayey, stipple: sandy, stipple with small circles: conglomeratic sediments; crosses: Precambrian crystalline rocks. Curves below show positions of dated samples (heavy dots) in various numbered fault blocks relative to the standard Salvador curve (see Fig. 4). After Martin and others (1984).

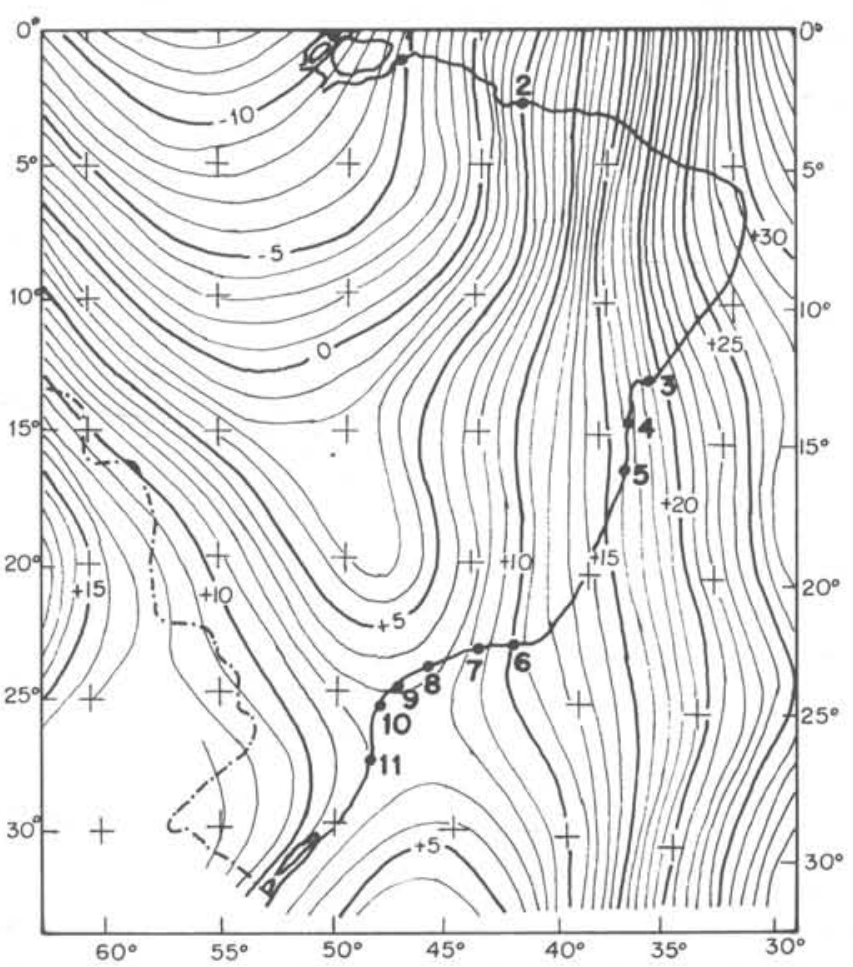

Figure 6: A geoid map of Brazil. Contours in metres. 1: Belém, 2: São Luis, 3: Salvador,

4: Ilhéus, 5: Caravelas, 6: Rio de Janeiro, 7: Angra dos Reis, 8: Santos, 9: Cananéia, 10: Paranagua and 11- Florianópolis. After Martin and others (1985).

Florianópolis, again has the same shape as that of Salvador, with a downwards shift, although not as much as the Paranaguá curve.

\section{Commentary on Holocene Variation Curves}

It is clear from Figure 4 that in all sectors the relative sea level has been higher than at present, with a maximum always occuring at about $5,100 \mathrm{yBP}$. All the curves have the same general shape, though some are shifted vertically. All sectors seem to have experienced after $5,100 \mathrm{yBP}$ two rapid oscillations of relative sea level of 2 to $3 \mathrm{~m}$, too large to be glacio-eustatic in origin.

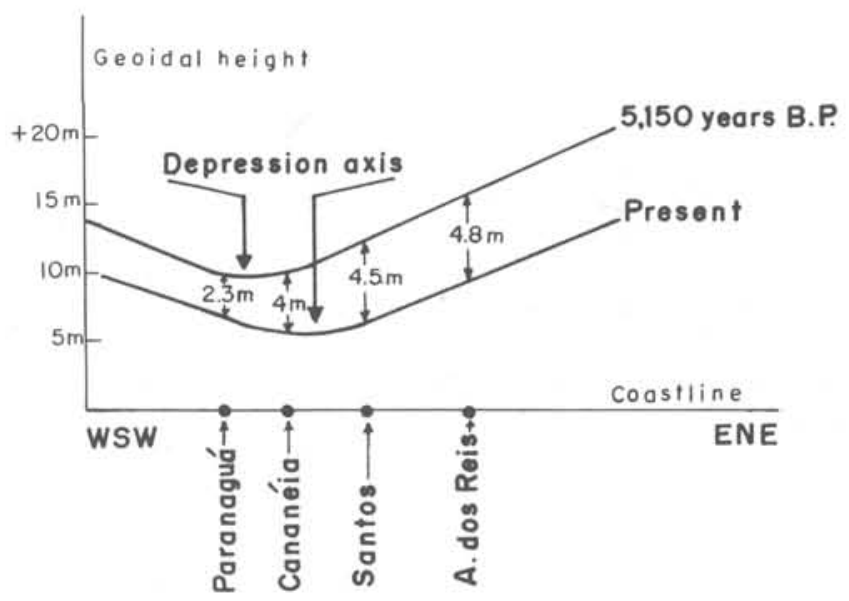

Figure 7: Present geoid profile between Paranagua and Angra dos Reis compared to that about 5,150 years ago. Vertical axis indicates geoidal height. After Martin and others (1985). 
In some well-delineated coastal sectors it has been possible to demonstrate Holocene beach-line shifts as a consequence of vertical neotectonic movements. For instance, in the Bay of Todos os Santos (State of Bahia), located on the Recôncavo graben, vertical movements have resulted in pronounced shifts of Holocene shorelines (Fig. 5). The same is true for parts of the coast of Rio de Janeiro State affected by the Guanabara graben and south of Cap of Sao Tomé, near Macae on Figure 2. Some parts of the coasts, for example, in the State of Sao Paulo, may have been affected by regional flexures, but this phenomenon apparently did not have a very great influence at the time of the Holocene.

In all the sectors illustrated in Figure 4, with the exception of Angra dos Reis, there is a record of marine terraces about 123,000 years old (Barrier III of Fig. 3). Nowhere do the innermost parts of this terrane, of roughly the same age, exhibit significant differences in elevation. If the shift of almost $1.5 \mathrm{~m}$, in the maximum height at $5,100 \mathrm{yBP}$ between the sectors of Salvador and Paranaguá were tectonic in origin, the records of the high marine level of 123,000 yBP would be shifted very greatly (almost $60 \mathrm{~m}$ ), which is not at all the case. Thus, it is likely that the shifts observed between certain sectors curves are the results of deformation of the geoid surface.

An examination of the geoid map of Brazil (Fig. 6) shows that the part of the north-south coast of Bahia State containing the Salvador, Ilhéus and Caravelas sectors is more or less parallel to the geoid contours. On the other hand, the part of the coast containing the Angra dos Reis, Santos, Cananéia and Paranaguá sectors runs approximately northeast-southwest, cutting obliquely across the lines of equal geoid height. A horizontal east-west or north-south displacement of the geoid relief would have no effect on the first three curves, but would trigger a shift of the others. For example, the submersion phase that affected a major part of the Brazilian coast before 5,100 yBP could have been associated with a temporary elevation of the geoid with the subsequent emersion related to a lowing of the same surface. In fact, a slight displacement of the geoid relief could explain the shifts observed between the curves of Angra dos Reis, Santos, Cananéia and Paranaguá, as shown schematically in Figure 7.

Thus, the high Holocene marine levels of Brazil, which can be neither glacio-eustatic nor tectonic in origin, may be explained, at least in part, by regional uplift of the overall geoid surface prior to 5,100 yBP, followed by its sinking and minor eastwards displacement. Similarly, regional depression of the geoid, followed by uplift on a scale of centuries, can explain the rapid oscillations since 5,100 years ago.

\section{Evolution of the Coastal Plains of Central and Southern} Brazil

Sea-level variations associated with climatic changes have been the principal factors in the development of Brazil's littoral plains. A fairly precise evolutionary model has been proposed for the Bahia coast, and this is valid also for the entire coast between Macaé and Recife. In contrast, for the southern half of the São Paulo coast, through Paraná and Santa Catarina, this model is only partly applicable for local reasons, and the Barrier I deposits occur only in the Rio Grande do Sul coastal plain. For the Macaé-Recife coast the following stages can be distinguished (Fig. 8).

During the Pliocene, the climate must have been hot and humid for a long time, for a very thick weathering mantle was formed. As the climate became drier (semi-arid) at the end of the Pliocene, the vegetation cover disappeared and this mantle was exposed to erosion, facilitated by a simultaneous uplift of the continent. The products of this erosion were deposited at the foot of rises in the form of coalescing alluvial cones (Fig. 8A). These continental deposits, which occur from Rio de Janeiro to the mouth of the Amazon River, are known as the Barreiras Formation. At the time of their deposition, relative sea level must have been appreciably below its present elevation, for the Barreiras Formation cover part of the present continental shelf.

The return to a humid climate, coinciding with a relative sea-level rise (the Old Transgression), marked the end of the deposition of the Barreiras Formation. The limit reached by the maximum of this transgression is indicated by a line of relict cliffs eut through the Barreiras Formation (Fig. 8B).
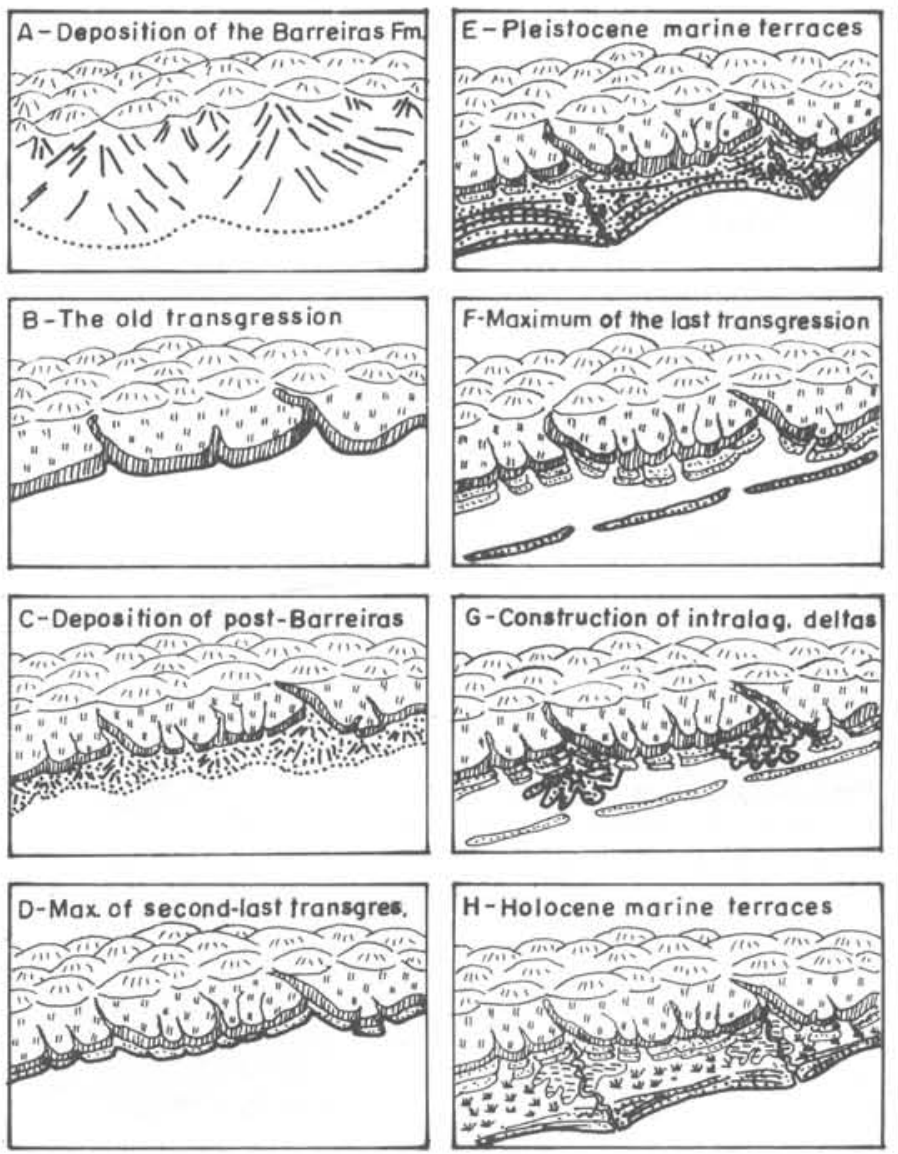

Figure 8: General model of evolution of the coastal plain between Macaé (Rio de Janeiro) and Recife (Pernambuco). After Martin and others (1986).

A new climatic change subsequently took place in conjunction with a lowering of relative sea level. The region once again became semi-arid, the vegetation cover was substantially reduced, and partial erosion of Barreiras Formation sediments took place. The resulting deposits, recorded only on the coasts of Bahia and Sergipe, are known as the Post Barreiras Continental Formation. They accumulated at the foot of rises, and in particular along the bases of the cliffs in the Barreiras sediments (Fig. 8C).

About $123,000 \mathrm{yBP}$, as shown above, relative sea level was about $8 \pm 2 \mathrm{~m}$ above the present level. During this transgression, the continental deposits formed during the preceding stage were partially or totally eroded, and the lower reaches of waterways and valleys carved into the Barreiras Formation were drowned and transformed into estuaries and lagoons (Fig. 5D).

A new regression then followed, and sandy terraces covered with littoral belts were formed in the presence or absence of waterways (Fig. $8 \mathrm{E}$ ). These older belts exhibit characteristics very different from those of more recent ones, enabling them to be distinguished very easily on aerial photographs. Between about 123,000 and $7,000 \mathrm{yBP}$, the relative sea level remained below the present one, as much as $110 \mathrm{~m}$ below approximately 17,000 years ago. 
Then some 7,000 years ago, relative sea level reached the present elevation and passed through it to a maximum of 4 to $5 \mathrm{~m}$ above present MSL about 5,100 years ago. The most common manifestation of this coastal drowning was the formation of barrier-island and lagoon systems (Fig. 8F). When a waterway opened up into one of these lagoons, an intra-lagoon delta was formed as at the mouths of the Rio Doce and Rio Paraiba do Sul, with dimensions varying as a function of the lagoon and waterway sizes (Fig. 8G).

Approximately 5,100 years ago, relative sea level began gradually to fall to its present position, although two rapid oscillations did occur between 4,000 and $3,600 \mathrm{yBP}$, and between 3,000 and 1,500 yBP. During the emersion stages littoral belts clung to the outer part of barrier islands, the lagoons tended to dry up, and the waterways opening into them flowed directly into the ocean (Fig. 8H).

\section{Final Comment}

The existence of large Quaternary coastal plains is one of the characteristics of the central and southern part of the Brazilian coast. Some plains are situated at the mouth of a large waterway, but others have no connection with either a present or a previous waterway. A second feature of this coast is that it was, as opposed to other regions of the world, submerged until about $7,000 \mathrm{yBP}$, and has, on the average, been above sea level since. A third characteristic of this region is that it is a high-energy coast, where littoral drift currents play an essential role in the transport of coarse sediments.

Prof. K. Suguio is based at the USP Institute of Geosciences (Universidade de São Paulo, CP 20899, 01498 São Paulo, Brazil). He is President of the Brazilian Association of Quaternary Studies, and of the Americas Subcommission of INQUA Commission on Quaternary Shorelines. He now concentrates on the Quaternary of the Brazilian coast.

Dr. J.-M. Flexor is based at the Department of Geophysics of the National Observatory (CNPq, Rio de Janeiro, RJ-Brazil), where he works on geophysical problems applied to the study of mean sealevel oscillations.

Dr. L. Martin is associated with the Institut Français de Recherche pour le Développement en Coopération (ORSTOM), and since 1974 has been participating in the research on the Brazilian coast with several Brazilian institutions including USP.

\section{References}

Fairbridge, R.W., 1961. Eustatic changes in sea-level. Physics and Chemistry of the Earth, v. 4, p. 99-185.

Martin, L., Bittencourt, A.C.S.P., Flexor, J.M. and VilasBoas, G.S., 1984. Evidência de um tectonismo quaternario nas costas do Estado de Bahia. XXXIII Congresso Brasileiro Geologia, Anais 1, p. 19-35.

Martin, L., Dominguez, J.M.L. and Suguio, K., 1986. Consequence of relative sea-level changes during the Quaternary on sandy coastal sedimentation: Examples from Brazil. In: Quaternary of South America and Antaretic Peninsula, Balkema, v. 4, p. 119-135.

Martin, L., Flexor, J.M., Blitzkow, D. and Suguio, K., 1985. Geoid change indications along the Brazilian coast during the last 7,000 years. Proceedings of Vth International Coral Reef Congress, Tahiti, v. 3 , p. 85-90.

Martin, L., Suguio, K., Flexor, J.M., Dominguez, J.M.L., Bittencourt, A.C.S.P., 1987. Quaternary evolution of the central part of the Brazilian coast: The role of relative sealevel variations and the shoreline drift. Unesco Reports in Marine Science, v. 43, p. 97-145.

Martin, L., Suguio, K., Flexor, J.M., in press. Hauts niveau marins pléistocènes du littoral brésiliens. Palaeogeography, Palaeoecology, Palaeoclimatology.

Mörner, N.A., 1980. Eustasy and geoid changes. Journal of Geology. v. 84, no. 2, p. 123-152.

Mörner, N.A., 1984. Interaction and complexity of sea-level changes, vertical crustal movements and geoid deformations. Symposium on Neotectonics and Sea-Level Variations in the Gulf of California area, Hermosillo. Universidad Nacional Autonoma de México, Abstracts Volume, p. 129.

Pirazzoli, P.A., 1988. Sea-level correlations: applying IGCP results. Episodes, v. 11, no. 2, p. 111-116.

Suguio, K., Martin, L., Bittencourt, A.C.S.P., Dominguez, J.M.L., Flexor, J.M., Azevedo, A.E.G. de, 1985. Flutuações do nível relativo do mar durante o Quaternário Superior ao longo do litoral brasileiro e suas implicações na sedimentação costeira. Revista Brasileira Geociências, v. 15 , no. 4, p. 273-286.

Van de Plassche, O. (ed.), 1986. Sea-level research; A manual for the collection and evaluation of data. Contribution to IGCP projects 61 and 200 . Geobooks, U.K., 618 p.

Villwock, J.A., Tomazelli, L.J., Loss, E.L., Dehnhardt, E.A., Horn Filho, N., Bachi, F.A. and Dehnhardt, B.A., 1986. Geology of the Rio Grande do Sul Coastal Province. Quaternary of South America and Antaretic Peninsula, v. 4, p. 79-97.
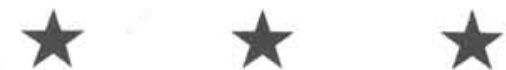